\title{
Selenium Stabilized Carbenium Ions on Organic Synthesis
}

\author{
Claudio C. Silveira, and Enrique L. Larghi \\ Departamento de Química, Universidade Federal de Santa Maria, UFSM, C.P. 5001, \\ 97105-900 Santa Maria - RS, Brazil; e-mail: silveira@quimica.ufsm.br
}

Received: August 10, 1998

\begin{abstract}
Este artigo resume as aplicações sintéticas de íons de carbenio estabilizados por grupos organoselênio. São descritas reações de diferentes tipos de íons de carbenio estabilizados por selênio com compostos aromáticos, éteres enólicos de silício, alilsilanos/alilestananas e alcenos.

This review summarizes the synthetic application of selenium stabilized carbenium ions. Are presented reactions of different types of selenium stabilized carbenium ions with aromatic compounds, silyl enol ethers, allylsilanes/allylstannanes and alkenes.
\end{abstract}

Keywords: selenium, carbenium ions, organic synthesis

\section{Introduction}

Organoselenium compounds have been known for a long time as versatile reagents in organic chemistry. In the last years there has been a considerable development of selenium-based methods for organic synthesis ${ }^{1}$. Many of these methods are currrently been used as standard procedures to introduce new functional groups under mild conditions. From the several areas of interest in organoselenium chemistry, selenium stabilized carbocations has emerged as a useful class for interesting transformations and new methods for carbon-carbon bond formation.

Aspects related to heterosubstituted carbenium ions, like their formation, structure and stability, has been very well studied and revised by Hevesi in the last years ${ }^{2}$, and will not be the subject of this article. In the following chapter we will detail synthetic aspects of selenium stabilized carbocations as electrophiles.

\section{Synthetic Applications}

Several new reactions were developed in the last years using the capability of an organoselenium group to stabilize an adjacent carbenium ion. These carbenium ions were generated from different selenium species and reacted with several nucleophiles, like silyl enol ethers, alkenes, allylsilanes/allylstannanes and aromatic compounds. In the following, we will be presenting these reactions in detail.

\section{Reaction of selenium stabilized carbenium ions with aromatic compounds}

The first aplication of this chemistry in order to produce a new carbon-carbon bond, was made by the use of selenoallyl cations in reaction with $N$-methyl-pyrrole (1) and furan $(\mathbf{2})^{3}$. These carbocations, stabilized by both selenium and allylic resonance, were generated in situ from a mixture of $E$ and $Z$ 1,3-bis(methylseleno)-propene (3) and 1,3bis(phenylseleno)-propene (4) mediated by silver perchlorate and sodium carbonate in nitrometane to give adducts like 5, as depicted in Fig. 1.

The reaction proceed smothly, with relatively good yields and stereospecificity. In the case of N-methyl-pyrrole variable ratios of regioisomers were obtained. After reaction are recovered important quantities of the starting material but one the isomers when are used as $Z$ and $E$ mixture. There have not been detected products derived of

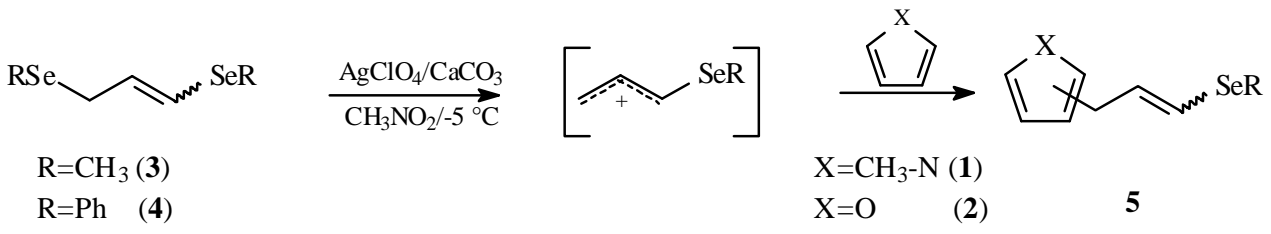

Figure 1. 
a $[4+3 \rightarrow 7]$ cycloaddition. This latter reaction occurs with allyl cations substituted at position 2 , especially with 2 oxyallyl systems ${ }^{3}$.

The same type of reaction have been exploited using other sources of allylic cationic species, like $\beta$-bromovinyl selenides 6a-f and electron-rich aromatic compounds as furan, $N$-methyl-pyrrole, thiophene and 1,3,5-trimethoxybenzene ${ }^{4}$.

Reagents like $6 \mathbf{a}$ and $\mathbf{6 b}$ have been prepared by addition<smiles>[R]C([R])=C([SeH])C([R3])Br</smiles>

$$
\begin{aligned}
& 6 \text { a: } \mathrm{R}_{1}=\mathrm{H}, \mathrm{R}_{2}=\mathrm{Cl}, \mathrm{R}_{3}=\mathrm{H} ; \text { b: } \mathrm{R}_{1}=\mathrm{H}, \mathrm{R}_{2}=\mathrm{Br}, \mathrm{R}_{3}=\mathrm{H} ; \\
& \text { c: } \mathrm{R}_{1}=\mathrm{R}_{2}=\mathrm{R}_{3}=\mathrm{H} ; \mathrm{d}: \mathrm{R}_{1}=\mathrm{H}, \mathrm{R}_{2}=\mathrm{R}_{3}=\mathrm{CH}_{3}(Z+E) ; \\
& \text { e: } \mathrm{R}_{1}=\mathrm{C}_{2} \mathrm{H}_{5}, \mathrm{R}_{2}=\mathrm{R}_{3}=\mathrm{H}(Z+E) ; \mathrm{f}: \mathrm{R}_{1}=\mathrm{R}_{2}=\mathrm{CH}_{3}, \mathrm{R}_{3}=\mathrm{H}
\end{aligned}
$$

of benzeneselenenyl chloride or bromide to propargyl bromide in dichloromethane solution at room temperature in $91 \%$ and $69 \%$, respectively. In an analogous fashion $\mathbf{6 c - f}$ have been prepared by the addition of benzeneselenenyl bromide to the corresponding allenes in quantitative yields ${ }^{4}$.

In Fig. 2 below, are presented some of the results obtained on the reaction of selenium stabilized carbenium ions with $\mathrm{N}$-methyl pyrrole, thiphene, furan and 1,3,5trimethoxybenzene. In the case of $\mathrm{N}$-methyl pyrrole or

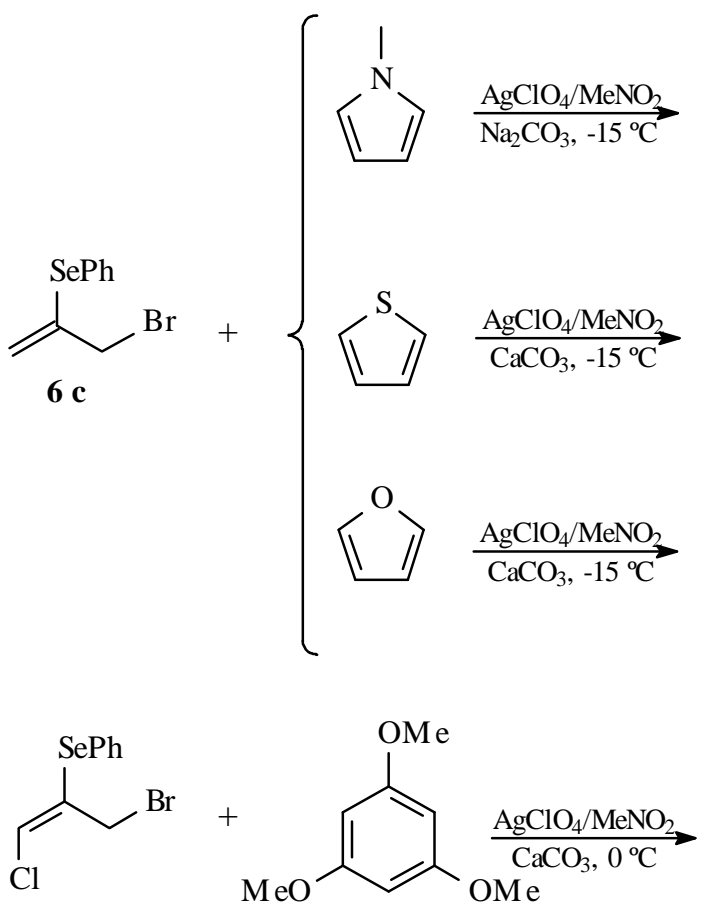

thiophene the products are obtained as a mixture of substituion at 2- and 3-position.

Although 1-selenoallyl cations 7 also undergo FriedelCrafts reactions with electron rich heterocycles, the nature of the final product is highly dependent on the susbstitution pattern of $\mathbf{8}$ and $\mathbf{9}$ as well as on the reaction solvent. This is illustred in Fig. 3 for the case of $N$-methyl pyrrole ${ }^{5}$.

Unsubstituted 8 and $9\left(\mathrm{R}_{1}=\mathrm{R}_{2}=\mathrm{H}\right)$ suffers nucleophilic attack by $N$-methyl pyrrole to give $\mathbf{1 0}$ (path a), whereas disubstituted 8 and $9\left(\mathrm{R}_{1}=\mathrm{R}_{2}=\right.$ alkyl, aryl) follows path $\mathrm{b}$. Compound 11 cannot be isolated most likely because of the high stability of cation 12 which in turn reacts with a second molecule of $N$-methyl pyrrole to give 13 or 14, depending on the solvent used. Paths a and b also shows some sensitivity to solvent, but the most spectacular effect is seen at the last stage of the reaction, i.e. attack of $\mathbf{1 2}$ by $N$-methyl pyrrole. 1,3-dipyrryl propenes $\mathbf{1 3}$ are almost exclusively formed in nitromethane, while regioisomers $\mathbf{1 4}$ are largely predominant when the reaction is carried out in DMF. The amounts of 15 and/or 14 can in each case be minimized by the use of an excess of $N$-methyl pyrrole.

One of the most interesting examples is the synthesis of porphyrins by this type of reagents. The high selective access to 1,1-dipyrryl propenes 14, suggest a straightforward synthesis of phorphirins bearing substitited vinyl groups at their meso-positions. Indeed, with the vinylselenoacetal 16 (a-g) like source of electrophile, a series of porphyrins 17 (a-g) have been prepared under the mild<smiles>C=C(Cc1ccn(C)c1)[SnH2]c1ccccc1</smiles><smiles>C=C(Cc1ccsc1)Sc1ccccc1</smiles><smiles>C=C(Cc1ccco1)c1ccccc1</smiles>

$6 \mathbf{a}$

Figure 2. 

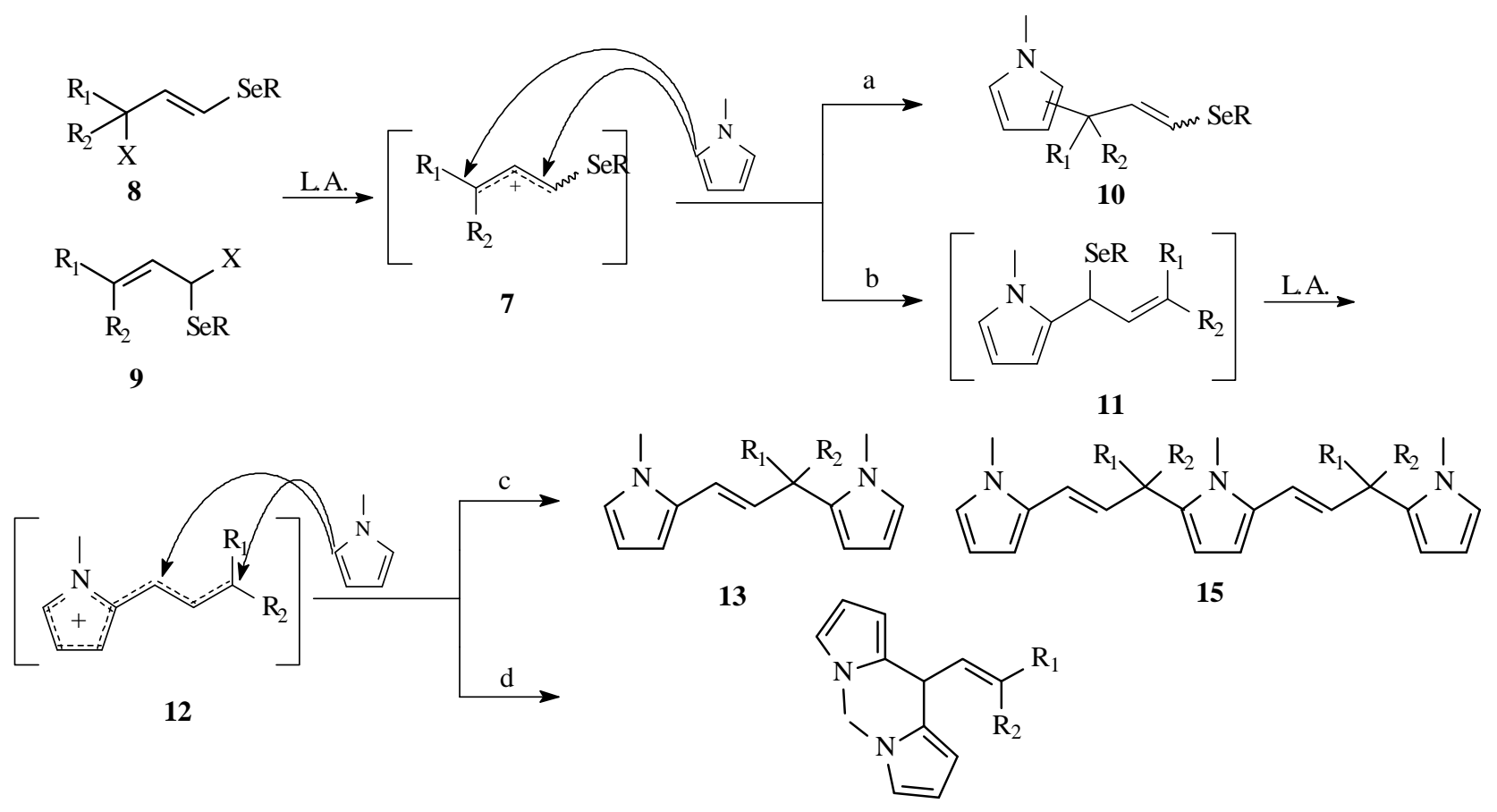

14

Figure 3.

conditions ${ }^{6}$ using the one pot reaction sequence outlined in Fig. 4.

Another synthesis of an interesting class of meso-porphyrins have been developed in the same fashion ${ }^{7}$. In this case, meso-tetraalkynyl porphyrins have been obtained from selenoacetals 18a-b derived from 2-butynal and 3phenylpropynal, with pyrrole and silver perchlorate in DMF. A further treatment with DDQ furnish the porphyrin 19a and 19b albeit in low yield (Fig. 5).

The use of selenocarbenium ions containing an acyl moiety and generated under Friedel-Crafts conditions have proved to be an efficient route to aromatic derivatives of phenyl acetic acids ${ }^{8}$. The interest in this synthetic route is due to that direct introduction of a two carbon unit contain- ing an acyl group with an $\alpha$-substituent, under these conditions, into an aromatic ring is expected to be difficult, owing to the desactivation of the intermediary electrophilic complex by the electronegative acyl group. The presence of an organoselenium moiety at the $\alpha$-position of the acyl group could circunvent this problem.

The synthetic procedure involves treatment of aromatic hydrocarbons with a mixture of ethyl $\alpha$-bromo- $\alpha$-phenylseleno acetate 20a and ethyl $\alpha$ - $\alpha$-bis-(phenylseleno) acetate $20 \mathrm{~b}$ and $\mathrm{TiCl}_{4}$ at room temperature, affording the related benzylic selenides $\mathbf{2 2} \mathbf{a}-\mathbf{h}$ as shown in Fig. 6. The mixture of ethylacetate derivative $\mathbf{2 0 a}$ and $\mathbf{2 0 b}$ is easily avaiable from reaction of ethyldiazoacetate with phenylselenenyl bromide in $\mathrm{THF}$ at $0{ }^{\circ} \mathrm{C}$ (Fig. 6). We observed lately

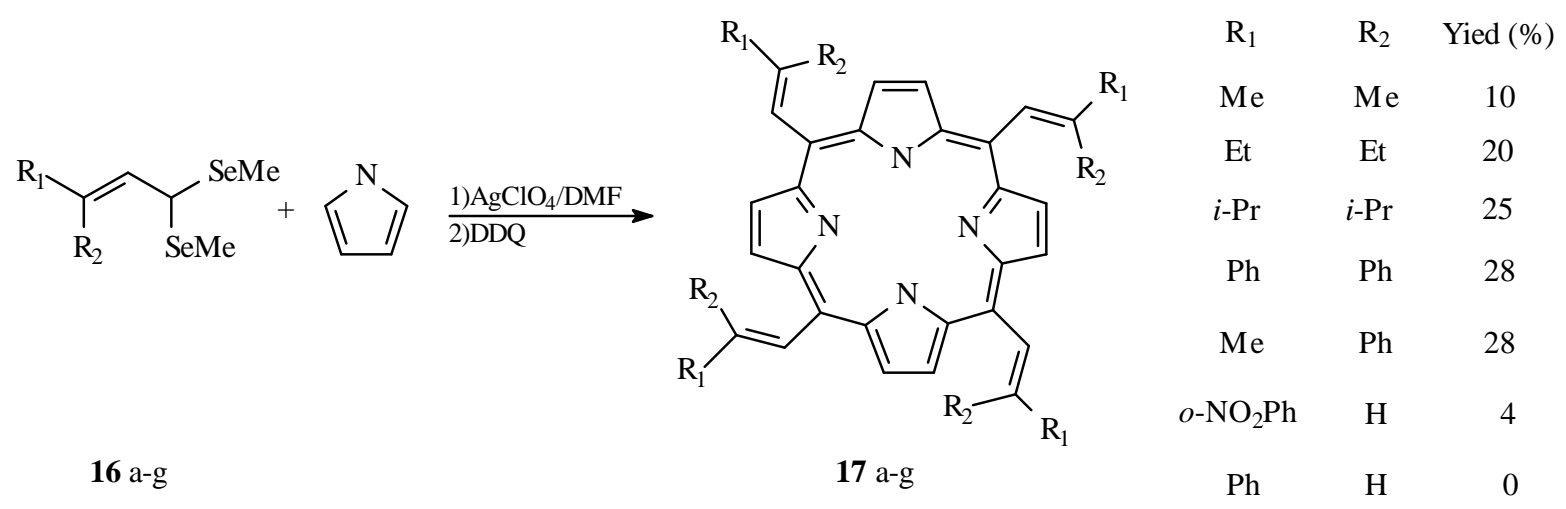

Figure 4. 


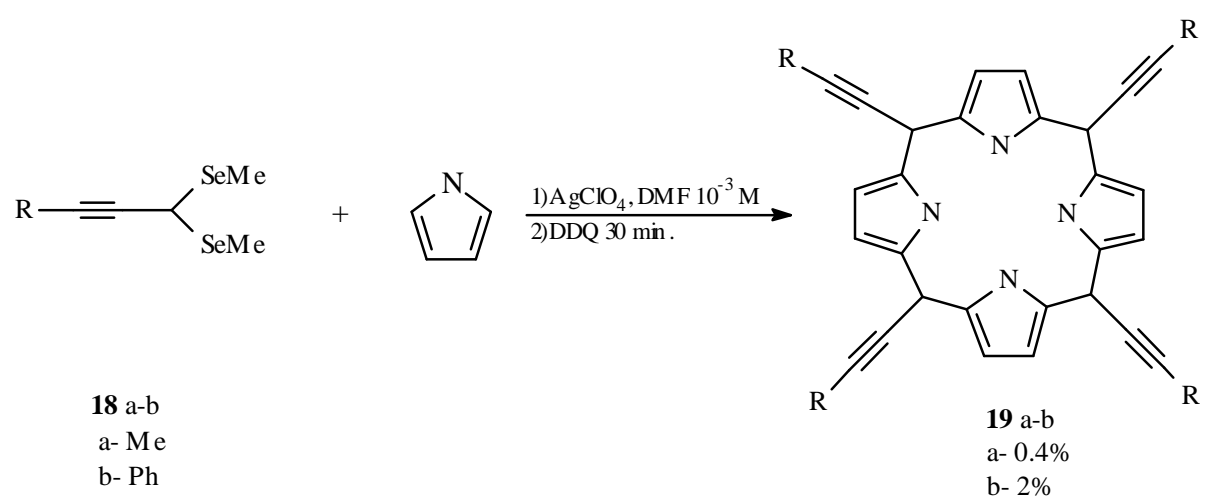

Figure 5.

that pure ethyl $\alpha$-bromo- $\alpha$-phenylseleno acetate can be obtained exclusively if the reaction is made by adding ethyl diazoacetate to a reflux benzene solution of $\mathrm{PhSeBr}$. The chloro derivative may also be prepared by the reaction of $\mathrm{PhSeCl}$ and ethyldiazo acetate, as the sole product ${ }^{9}$. Both these reagents gives the Friedel-Crafts reaction under the same conditions described. Also, has been developed an efficient way to remove the phenylseleno group from the alkylation products. By treatment of benzylic selenide $\mathbf{2 2}$ with catalytic amounts of thienylditelluride in ethanol and equimolar amounts of sodium borohydride under basic conditions ${ }^{10}$ the corresponding deselenate derivative $\mathbf{2 3}$ is formed, as depicted in Fig. 6. The result obtained by the Friedel-Crafts reaction are presented in Table 1.

\section{Reaction of $\alpha$-phenylseleno carbenium ions with silyl} enol ethers

The use of selenoacetals $\mathbf{2 4 a - f}$ in order to produce synthetically available carbenium ions have been developed succesfully ${ }^{11}$. The reaction of these compounds with silyl enol ethers like 25a mediated by a Lewis acid catalyst, gave the $\beta$-seleno carbonyl derivative $\mathbf{2 6}$ in good to excellent yields as depicted in Fig. 7.

In Table 2 are reproduced the yields obtained in the former reaction, using 2 eq. of cyclohexanone silyl enol ether, 1 eq. of selenium reagent and 2 eq. of Lewis acid in dichloromethane.
Table 1.

\begin{tabular}{cccc}
\hline $\mathbf{2 1}$ & $\begin{array}{c}\text { Aromatic } \\
\text { hydrocarbon }\end{array}$ & $\begin{array}{c}\text { Yield (\%) } \\
\text { [isomer ratios] }\end{array}$ & $\begin{array}{c}\text { Reaction time } \\
(\mathrm{min})\end{array}$ \\
\hline $\mathrm{a}$ & benzene & 87 & 50 \\
$\mathrm{~b}$ & toluene & $68[2: 1]$ & 75 \\
$\mathrm{c}$ & ethylbenzene & $75[1.5: 1]$ & 30 \\
$\mathrm{~d}$ & naphtalene & 94 & 50 \\
$\mathrm{e}$ & phenantrene & 76 & 40 \\
$\mathrm{f}$ & $p$-cymene & $64[1: 2]$ & 60 \\
$\mathrm{~g}$ & mesitylene & 82 & 60 \\
$\mathrm{~h}$ & $p$-xylene & 76 & 45 \\
\hline
\end{tabular}

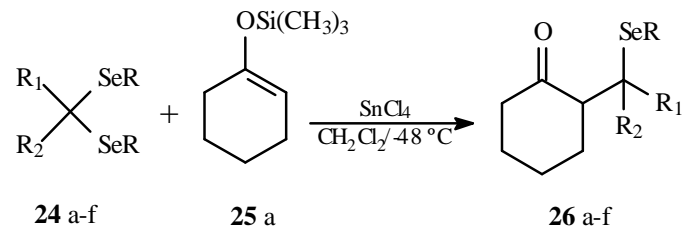

Figure 7.

By inspection of values reflected in the previous table, can be observed that the presence of bulkier groups arround the cationic center decrease the yields of the reaction (entries $d$ and e), while the presence of a phenyl group increase

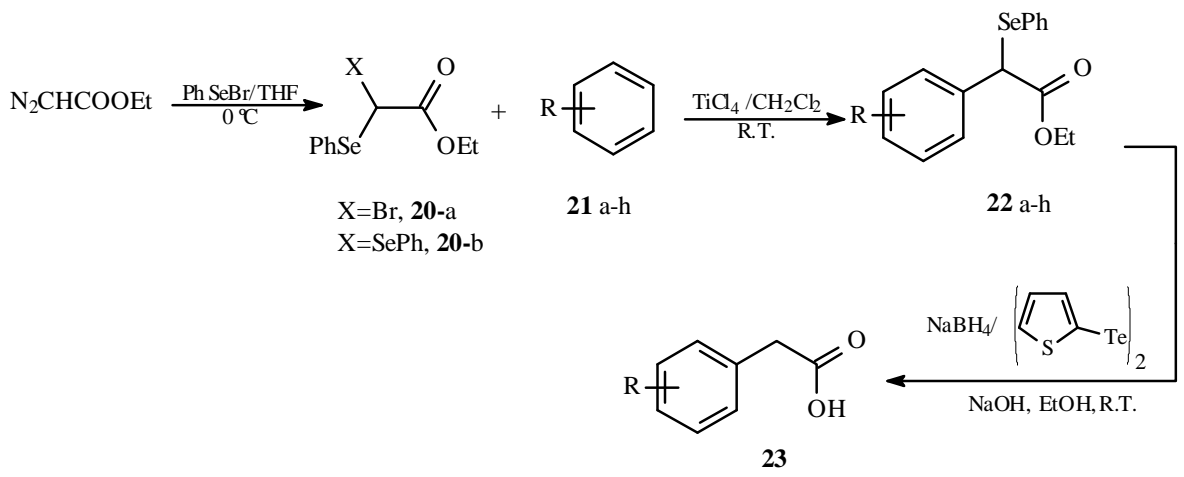

Figure 6. 
Table 2.

\begin{tabular}{cccccc}
\hline $\mathbf{2 4}$ & $\mathrm{R}$ & $\mathrm{R}_{1}$ & $\mathrm{R}_{2}$ & $\begin{array}{c}\text { React. } \\
\text { time (h) }\end{array}$ & $\begin{array}{c}\text { Yield } \\
(\%)\end{array}$ \\
\hline $\mathrm{a}$ & $\mathrm{CH}_{3}$ & $\mathrm{CH}_{3}$ & $\mathrm{CH}_{3}$ & 1.5 & 84 \\
$\mathrm{~b}$ & $\mathrm{CH}_{3}$ & $\mathrm{C}_{6} \mathrm{H}_{5}$ & $\mathrm{H}$ & 2 & 89 \\
$\mathrm{c}$ & $\mathrm{CH}_{3}$ & $\mathrm{C}_{6} \mathrm{H}_{5}$ & $\mathrm{CH}_{3}$ & 1.5 & 81 \\
$\mathrm{~d}$ & $\mathrm{CH}_{3}$ & $\mathrm{CH}_{3} \mathrm{CH}_{2}$ & $\mathrm{CH}_{3}$ & 1.5 & 61 \\
$\mathrm{e}$ & $\mathrm{CH}_{3}$ & $\mathrm{CH}_{3} \mathrm{CH}_{2}$ & $\mathrm{CH}_{3} \mathrm{CH}_{2}$ & 1.5 & 49 \\
$\mathrm{f}$ & $\mathrm{C}_{6} \mathrm{H}_{5}$ & $\mathrm{CH}_{3}$ & $\mathrm{CH}_{3}$ & 1.5 & 97 \\
\hline
\end{tabular}

the yields by the effect of making the formation of cation easier.

Furthermore the seleno alkylation of $\mathbf{2 4 a}$ with a variety of silyl enol ethers (Fig. 8), in the conditions described previously, gave raise to good yields.

In a similar methodologie, we found that $\alpha$-halo- $\alpha$ phenylseleno alkanes 27 reacts with silyl enol ethers in the presence of $\mathrm{TiCl}_{4}$ to give the corresponding aducts $\mathbf{2 8}$ in high yields ${ }^{12}$, as described in Fig. 9.

$\alpha$-Halo- $\alpha$-(organoseleno)-alkanes 27 are easily accesible throgh the reaction of arylselenenyl bromide with diazoalkanes $^{13}$, addition of hydrogen halides to vinylic selenides $^{14}$ and by reaction of carbonyl compounds with selenophenol in presence of hydrogen halides ${ }^{14}$.

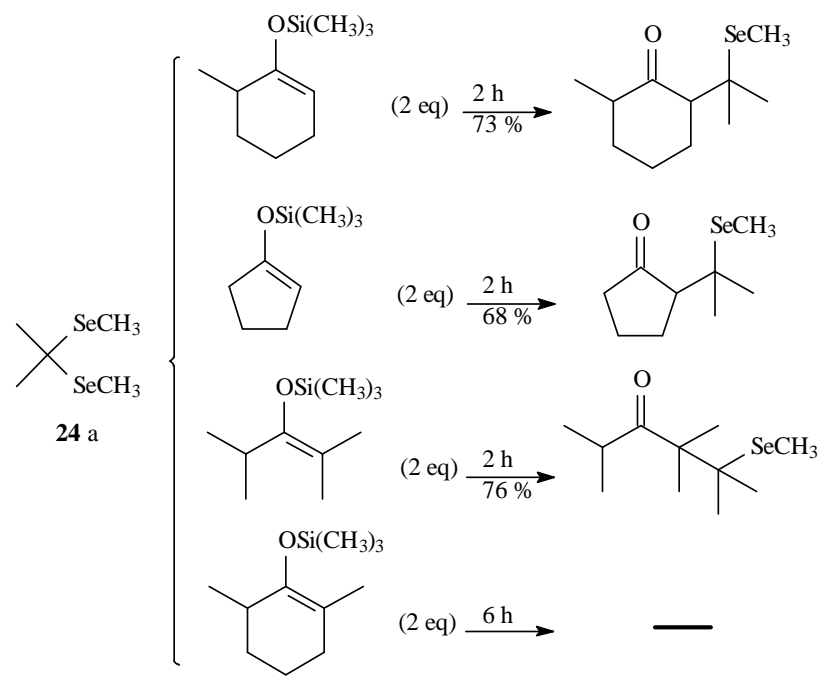

Figure 8.<smiles>[R]/C(C)=C(/[13CH3])O[Na]</smiles><smiles>[R]C([R])([R])Sc1ccccc1</smiles>

(1)<smiles>ClCC1CCCCC1(Cl)Cl</smiles>

In the Table 3 are presented the results of this study, showing the generality of the method.

Worth of note it is that by this methodology it was posible to obtain the alkylation products of silyl enol ethers with $\alpha$-bromo- $\alpha$-(phenylseleno)-methane and 1-bromo-1(phenylseleno)-ethane, products not formed by the reaction of alkylation of silyl enol ethers with selenoacetals described above ${ }^{11}$. This result suggests that the stability of the carbenium ion it is not the only factor affecting the reaction course. Also, we were able to alkylate the sterically crowded 1-trimethylsilyloxy-2,3-dimethylcyclohexene in good yileds using 1-bromo-1-(phenylseleno)ethane.

The easily available tris-(phenylseleno)methane reacted with trimethylsilyl enol ethers mediated by Lewis acids to give $\beta, \beta$-bis-(phenylseleno)-carbonyl compounds ${ }^{15}$, as described on Fig. 10.

In this case the presence of a second selenium atom in the carbenium ion should enhance the stability of the intermediate, facilitating its formation and thus leading to the alkylated product in good yield. The Table 4 presents the results of this study, by reaction with the silyl enol ether from different carbonyl compounds.

Table 3.

\begin{tabular}{|c|c|c|c|}
\hline Product & Yield (\%) & $X$ & $\begin{array}{l}\text { Reaction } \\
\text { Temp. }\left({ }^{\circ} \mathrm{C}\right)\end{array}$ \\
\hline & 57 & $\mathrm{Br}$ & -23 \\
\hline & 85 & $\mathrm{Br}$ & -23 \\
\hline & 65 & $\mathrm{Cl}$ & -78 \\
\hline & 50 & $\mathrm{Br}$ & -23 \\
\hline & 77 & $\mathrm{Br}$ & -23 \\
\hline & 26 & $\mathrm{Cl}$ & -78 \\
\hline & 20 & $\mathrm{Br}$ & -23 \\
\hline & 74 & $\mathrm{Br}$ & -23 \\
\hline & - & $\mathrm{Cl}$ & -78 \\
\hline
\end{tabular}

Figure 9. 
<smiles></smiles>
$\mathrm{R}_{1}=\mathrm{H}$, alkyl, OEt

29<smiles>[R]C(C(=O)I)C([SeH])[SeH]</smiles>

30

Figure 10.

Similar results were described at the same time by Hevesi and Nsunda ${ }^{16}$, with additional that tris-(methylseleno)-methane could also be employed as the carbenium ion source.

Soon later Hevesi and Lavoix ${ }^{17}$ described the reaction of 1-(trimethylsilyloxy)-ciclohexene with selenium stabilized allylic carbocations, as described on the Fig. 11.

The electrophilic species could be generated from 1,3bis-(methylseleno)-propenes and 3-hydroxy-vinylselenides. With the former, tin tetrachloride showed to be the best catalyst and zinc chloride for the last one. In both cases the reactivity, the efficient and the regiochemistry of the carbenium ions on these reactions were very dependent on the substituents on the selenium reagent. These results are better resumed on Table $5^{17}$.
In the course of our studies on selenium-stabilized carbenium ions, we observed that $\alpha$-chloro- $\alpha$-phenylselenoesters ${ }^{18}$ 33a-b reacted with silyl enol ethers 25 mediated by Lewis acids to give $\alpha$-phenylseleno- $\gamma$-keto esters 34 in fair to high yields, in very clean reactions as depicted in Fig. 12.

Table 4.

Silyl enol ether

Table 5.

\begin{tabular}{|c|c|c|c|c|c|c|}
\hline \multirow[b]{2}{*}{31} & \multirow[b]{2}{*}{$\mathrm{R}^{1}$} & \multirow[b]{2}{*}{$\mathrm{R}^{2}$} & \multirow[b]{2}{*}{$\mathrm{X}$} & \multirow[b]{2}{*}{ Conditions } & \multicolumn{2}{|c|}{ Yield \% } \\
\hline & & & & & $32(32 a: 32 b)$ & $32 c$ \\
\hline $\mathrm{a}(E)$ & $\mathrm{H}$ & $\mathrm{H}$ & $\mathrm{SeMe}$ & 2 eq. $\mathrm{SnCl}_{4} / \mathrm{CH}_{2} \mathrm{Cl}_{2} /-40^{\circ} \mathrm{C} / 6 \mathrm{~h}$ & - & $27^{\mathrm{a}}$ \\
\hline$b^{b}$ & $\mathrm{H}$ & $\mathrm{Me}$ & $\mathrm{SeMe}$ & 2 eq. $\mathrm{SnCl}_{4} / \mathrm{CH}_{2} \mathrm{Cl}_{2} /-40^{\circ} \mathrm{C} / 6 \mathrm{~h}$ & $32(0: 100)$ & 18 \\
\hline$c^{c}$ & $\mathrm{Me}$ & $\mathrm{Me}$ & $\mathrm{SeMe}$ & 2 eq. $\mathrm{SnCl}_{4} / \mathrm{CH}_{2} \mathrm{Cl}_{2} /-40^{\circ} \mathrm{C} / 2 \mathrm{~h}$ & $69(80: 20)$ & - \\
\hline $\mathrm{d}(E)$ & $\mathrm{H}$ & $\mathrm{H}$ & $\mathrm{OH}$ & $1.2 \mathrm{eq} \mathrm{ZnCl}_{2} / \mathrm{CH}_{3} \mathrm{NO}_{2} /$ R.T.T$/ 0.5 \mathrm{~h}$ & - & 15 \\
\hline e $(Z)$ & $\mathrm{H}$ & $\mathrm{Me}$ & $\mathrm{OH}$ & $1.2 \mathrm{eq} \mathrm{ZnCl}_{2} / \mathrm{CH}_{3} \mathrm{NO}_{2} /$ R.T./3 h & $44(0: 100)$ & 9 \\
\hline $\mathrm{f}(Z)$ & $\mathrm{Me}$ & $\mathrm{Me}$ & $\mathrm{OH}$ & 1.2 eq $\mathrm{ZnCl}_{2} / \mathrm{CH}_{3} \mathrm{NO}_{2} / 0{ }^{\circ} \mathrm{C} / 1 \mathrm{~h}$ & $80(80: 20)$ & - \\
\hline & & & & $1.2 \mathrm{eq} \mathrm{ZnCl}_{2} / \mathrm{CH}_{3} \mathrm{NO}_{2} /-40^{\circ} \mathrm{C} / 1.5 \mathrm{~h}$ & $69(96: 4)$ & - \\
\hline
\end{tabular}

a) $51 \%$ of $31 \mathbf{a}(E+Z)$ recovered unreacted;

b) $31 \mathbf{b}$ is a $[1,3]$ sigmatropic mixture of the acetal and the related vinyl selenide;

c) $31 \mathrm{c}$ is in fact the pure acetal.

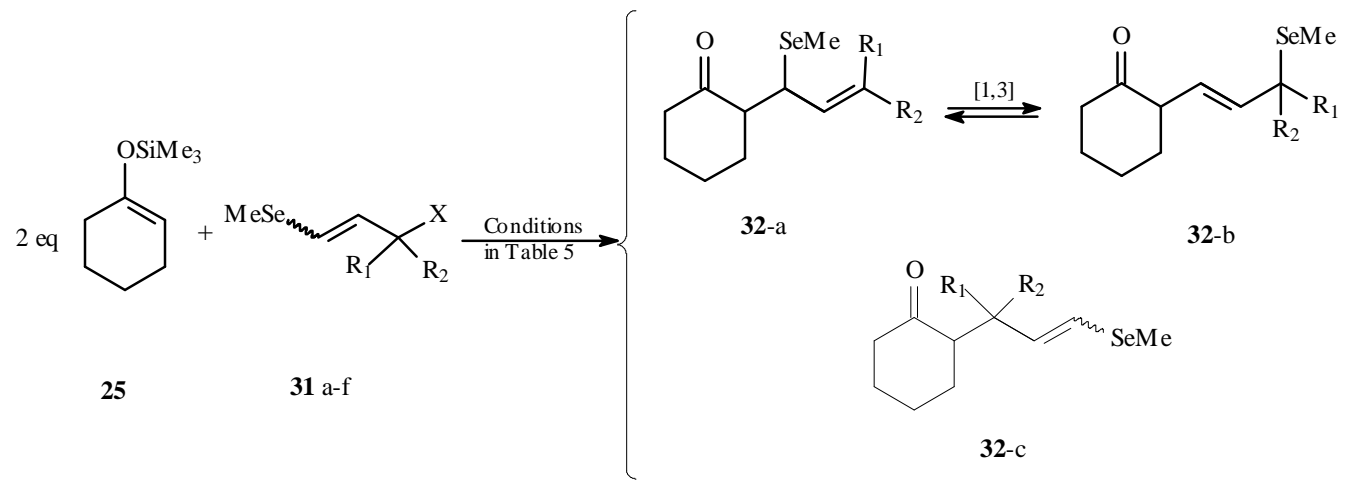

Figure 11. 
<smiles>[R]C(Cl)([SeH])C(=O)O</smiles>

33-a $\mathrm{R}=\mathrm{H}$ 33-b $\mathrm{R}=\mathrm{CH}_{3}$<smiles>CCC=C(C)CC</smiles>

25 a-e<smiles>CCCCCCCC</smiles><smiles>[R]C(C(=O)OCC)(c1ccccc1)C(C)C(C)=O</smiles>

34 a-i

Figure 12.

Thus, the treatment of a dichloromethane solution of 33a-b with 2.0 equivalents of $\mathbf{2 5 a - e}$ and $\mathrm{ZnBr}_{2}$ as Lewis acid, produces the desired adducts 34a-i (Fig. 12; Table 6).

From the results described in Table 6, it can be seen that the presence of an additional methyl group in the halide $33 \mathbf{b}$ causes a beneficial effect on the carbocation stabilization. The yields of the reaction of silyl enol ethers with ethyl $\alpha$-chloro- $\alpha$-phenylseleno propionate $\mathbf{3 3 b}$ in most cases studied are higher than with 33a, with reaction of silyl enol ether $\mathbf{2 5 b}$ being one exception (product $\mathbf{3 4 d}$; Table 6 ). The reactions of $\mathbf{3 3 b}$ were performed at $0{ }^{\circ} \mathrm{C}$, but we observed that for the reaction with ethyl $\alpha$-chloro- $\alpha$-phenylseleno acetate, better results could be achieved if the reaction was performed at a somewhat higher temperature (room temperature for cyclic ketones or $42{ }^{\circ} \mathrm{C}$ for acyclic ketones) as shown in Table 6. Among the various Lewis acid tried, $\mathrm{ZnBr}_{2}$ gave the best results, although $\mathrm{ZnCl}_{2}$ also reacted efficiently. When $\mathrm{AlCl}_{3}, \mathrm{TiCl}_{4}$ and $\mathrm{SnCl}_{4}$ were used, rapid decomposition of the silyl enol ether was observed by TLC and no products were detected.

Yoshimatsu and co-workers ${ }^{19}$ described the reaction of $S$-ethyl- $O$-silyl-enol ethers 36 with $\gamma$-chalcogen-substituted prop-2-ynyl cations to prepare $S$-ethyl-3-ethoxy-5(phenylchalcogeno)pent-4-ynethioates 37. These intermediates were converted to $\varpi$-chalcogen-substituted alkynyl amides 38 (in moderate yields), which were in sequence cyclized to 5-(phenylselenomethylene)-pyrrol-2ones 39, in accordance with Fig. 13.

In the Table 7 are reproduced the yields obtained for all S-ethyl-3-ethoxy-5-(phenylseleno)-pent-4-ynethioates $\mathbf{3 7}$.

\section{Reaction with allylsilanes and allylstannanes}

The first reaction studied of an organo-selenium stabilized carbenium ion with allylsilanes was the reaction described by Hermans and Hevesi ${ }^{20}$. They described the reaction of allyltrimethylsilane with selenoacetals mediated by tin tetrachloride to produce the corresponding

Table 7.

\begin{tabular}{lcc}
\hline $\mathrm{R}_{1}$ & $\mathrm{R}_{2}$ & Yield \% \\
\hline $\mathrm{H}$ & $\mathrm{H}$ & 90 \\
$\mathrm{Me}$ & $\mathrm{Me}$ & 73 \\
$\mathrm{H}$ & $\mathrm{Me}$ & 65 \\
$\mathrm{H}$ & $\mathrm{Ph}$ & 73 \\
$\mathrm{H}$ & $i$-Pr & 72 \\
\hline
\end{tabular}

Table 6.

\begin{tabular}{|c|c|c|c|c|}
\hline & Silyl Enol Ether & Product & Reaction temp. & Yield $(\%)^{\mathrm{a}}$ \\
\hline \multirow{2}{*}{$25 \mathrm{a}$} & & $34 \mathrm{a}, \mathrm{R}=\mathrm{H}$ & r.t. $^{\text {b }}$ & 60 \\
\hline & & $34 \mathrm{~b}, \mathrm{R}=\mathrm{Me}$ & $0{ }^{\circ} \mathrm{C}$ & 73 \\
\hline \multirow{3}{*}{$25 b$} & & $34 c, R=H$ & r.t. & 66 \\
\hline & & $34 c, R=H$ & $42{ }^{\circ} \mathrm{C}$ & 86 \\
\hline & & $34 \mathrm{~d}, \mathrm{R}=\mathrm{Me}$ & 0 & 80 \\
\hline \multirow{3}{*}{$25 \mathrm{c}$} & & $34 \mathrm{e}, \mathrm{R}=\mathrm{H}$ & r.t. & 47 \\
\hline & & $34 \mathrm{e}, \mathrm{R}=\mathrm{H}$ & $42{ }^{\circ} \mathrm{C}$ & 56 \\
\hline & & $34 \mathrm{f}, \mathrm{R}=\mathrm{Me}$ & $0 \mathrm{C}$ & 71 \\
\hline \multirow{2}{*}{$25 \mathrm{~d}$} & & $34 \mathrm{~g}, \mathrm{R}=\mathrm{H}$ & r.t. ${ }^{\mathrm{b}}$ & 42 \\
\hline & & $34 \mathrm{~h}, \mathrm{R}=\mathrm{Me}$ & $0{ }^{\circ} \mathrm{C}$ & 81 \\
\hline $25 \mathrm{e}$ & & $34 \mathrm{i}$ & $0{ }^{\circ} \mathrm{C}$ & 58 \\
\hline
\end{tabular}

a) Isolated yields;

b) Lower yields were observed at $42{ }^{\circ} \mathrm{C}$. 


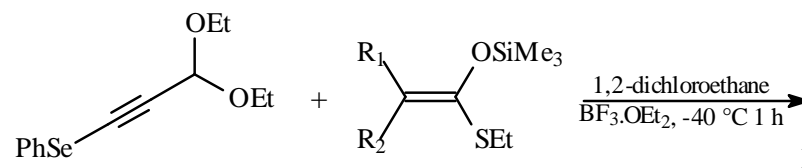

35<smiles></smiles>

39

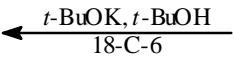<smiles>[R]NC(=O)C([R])([R])C(C#C[CH2])OCC</smiles>

38
Figure 13.

homoallylselenides $\mathbf{4 0}$ in moderate to good yields, in accordance with Fig. 14.

By the results described on Table 7 , one can observe that the yields of the products are very dependent on the substitution pattern of the selenoacetal. The ones derived from cyclohexanone or methylketones gives better yields than derived from aldehydes or internal ketones which could be accounted from electronic effects (stabilization of the intermediate carbenium ion for selenoacetals derived from aldehydes) or steric crowding around the electrophilic center (in the case of more substituted ketones). Table 8 presents the results obtained in this study.

Similar reactions of selenoacetals with allyltrimethylstannane were studied, and was observed that they occured at room temperature and in presence of zinc chloride or boron trifluoride etherate as catalyst. Compared to the above described reaction with allylsilane, the reactions with allyltributylstannane, as depicted by Fig. 15, gave yields in the same range and some selenoacetals that fails to react with allylsilanes [like 1,1-bis-(phenylseleno)-4-( $t$ butyl)-cyclohexene] do react with allyltributylstannanes. Besides, the reactions showed good stereoselectivity in

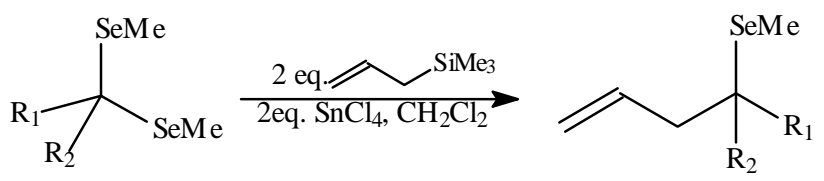

40

Figure 14.<smiles>[R]C(C)=CC[Sb]C(=O)C(C)C</smiles>

some examples depending on the substituion pattern and reaction conditions, as can be seen on Table 9, where are reproduced some examples of interest ${ }^{20}$.

Soon after was studied the coupling of mixed $(\mathrm{O}, \mathrm{Se})$ acetals with allyltrimethylsilane and allyltributylstannane mediated by a Lewis acid catalyst ${ }^{21}$. The methodology is illustred in Fig. 16.

In this study was expected that could be possible selectively produce homoallylethers or homoallyl selenides by carefull choice of the Lewis acid. Unfortunatelly this was not the case, since in almost all cases the homoallyl ethers were produced with different Lewis acid (for selected examples see Table 10). The main reason for this result

Table 8.

\begin{tabular}{lccc}
\hline $\mathrm{R}_{1}$ & $\mathrm{R}_{2}$ & Conditions & Yield \% \\
\hline $\mathrm{C}_{6} \mathrm{H}_{13}$ & $\mathrm{H}$ & $25^{\circ} \mathrm{C} / 1 \mathrm{~h}$ & 33 \\
$p-\mathrm{NO}_{2}-\mathrm{C}_{6} \mathrm{H}_{4}$ & $\mathrm{H}$ & $-40{ }^{\circ} \mathrm{C} / 2 \mathrm{~h}$ & 30 \\
$\mathrm{C}_{6} \mathrm{H}_{5}$ & $\mathrm{H}$ & $-40{ }^{\circ} \mathrm{C} / 4 \mathrm{~h}$ & 48 \\
$p-\mathrm{CH}_{3}-\mathrm{C}_{6} \mathrm{H}_{4}$ & $\mathrm{H}$ & $-40{ }^{\circ} \mathrm{C} / 4 \mathrm{~h}$ & 60 \\
$p-\mathrm{MeO}_{-} \mathrm{C}_{6} \mathrm{H}_{4}$ & $\mathrm{H}$ & $-40{ }^{\circ} \mathrm{C} / 2 \mathrm{~h}$ & 75 \\
$\mathrm{C}_{6} \mathrm{H}_{13}$ & $\mathrm{CH}_{3}$ & $-40{ }^{\circ} \mathrm{C} / 2 \mathrm{~h}$ & 69 \\
$\mathrm{C}_{3} \mathrm{H}_{7}$ & $\mathrm{C}_{3} \mathrm{H}_{7}$ & $-40{ }^{\circ} \mathrm{C} / 2.5 \mathrm{~h}$ & 35 \\
$\mathrm{C}_{3} \mathrm{H}_{7}$ & $\mathrm{CH}_{3}$ & $-40{ }^{\circ} \mathrm{C} / 5 \mathrm{~h}$ & 60 \\
$\mathrm{C}_{2} \mathrm{H}_{5}$ & $\mathrm{C}_{2} \mathrm{H}_{5}$ & $-40{ }^{\circ} \mathrm{C} / 1.5 \mathrm{~h}$ & 28 \\
$-\left(\mathrm{CH}_{2}\right)_{5}-$ & - & $-40{ }^{\circ} \mathrm{C} / 0.25 \mathrm{~h}$ & 60 \\
$\mathrm{C}_{6} \mathrm{H}_{5}$ & $\mathrm{CH}_{3}$ & $-40{ }^{\circ} \mathrm{C} / 2.5 \mathrm{~h}$ & 49 \\
\hline
\end{tabular}

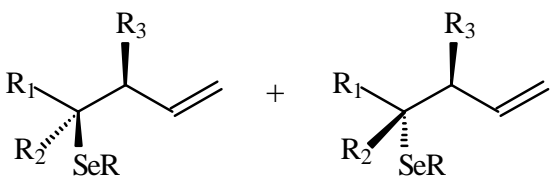

$$
\text { 41-syn 41-anti }
$$

Figure 15. 


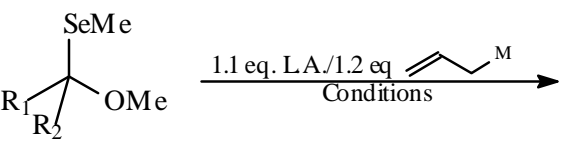

42<smiles>[R]C([R])(CC=C)OC</smiles>

43 a
$\overbrace{\mathrm{R}}^{\mathrm{SeMe}}$

$43 \mathrm{~b}$

$43 \mathrm{c}$

$\mathrm{M}=\mathrm{SiMe}_{3}, \mathrm{SnBu}_{3}$

b: $\mathrm{R}_{1}=\mathrm{n}-\mathrm{Hex} . \mathrm{R}_{2}=\mathrm{Me}$

c: $\mathrm{R}_{1}=\mathrm{Ph} \quad \mathrm{R}_{2}=\mathrm{H}$

Figure 16.

Table 9.

\begin{tabular}{lcccccccc}
\hline $\mathrm{R}_{1}$ & $\mathrm{R}_{2}$ & $\mathrm{R}_{3}$ & $\mathrm{R}$ & $\mathrm{L} . \mathrm{A}$. & $\mathrm{Solvent}$ & $\mathrm{T}\left({ }^{\circ} \mathrm{C}\right) / \mathrm{t}(\mathrm{h})$ & syn:anti & Yield \\
\hline $\mathrm{Ph}$ & $\mathrm{H}$ & $\mathrm{H}$ & $\mathrm{Me}$ & $\mathrm{BF}_{3} \cdot \mathrm{OEt}_{2}$ & $\mathrm{CH}_{2} \mathrm{Cl}_{2}$ & $20 / 16$ & - & 49 \\
$\mathrm{Ph}$ & $\mathrm{H}$ & $\mathrm{Me}$ & $\mathrm{Me}$ & $\mathrm{BF}_{3} \cdot \mathrm{OEt}_{2}$ & $\mathrm{CH}_{2} \mathrm{Cl}_{2}$ & $20 / 16$ & $95: 5$ & 12 \\
$\mathrm{Ph}$ & $\mathrm{H}$ & $\mathrm{Me}$ & $\mathrm{Me}$ & $\mathrm{BF}_{3} \cdot \mathrm{OEt}_{2}$ & $\mathrm{CH}_{2} \mathrm{Cl}_{2}$ & $20 / 72$ & $67: 33$ & 52 \\
$\mathrm{Ph}$ & $\mathrm{H}$ & $\mathrm{Me}$ & $\mathrm{Me}$ & $\mathrm{ZnCl}_{2}$ & $\mathrm{CH}_{2} \mathrm{Cl}_{2}$ & $20 / 24$ & $60: 40$ & 44 \\
$\mathrm{Ph}$ & $\mathrm{H}$ & $\mathrm{Me}$ & $\mathrm{Me}$ & $\mathrm{AlCl}_{3}$ & $\mathrm{C}_{6} \mathrm{H}_{5} \mathrm{CH}_{3}$ & $-40 / 2$ & $60: 40$ & 46 \\
$\mathrm{Ph}$ & $\mathrm{H}$ & $\mathrm{Me}$ & $\mathrm{Me}$ & $\mathrm{AlCl}_{3}$ & $\mathrm{CH}_{2} \mathrm{Cl}_{2}$ & $-40 / 2$ & $67: 33$ & 50 \\
$c-\mathrm{C}_{6} \mathrm{H}_{11}$ & $\mathrm{H}$ & $\mathrm{H}$ & $\mathrm{Me}$ & $\mathrm{AlCl}_{3}$ & $\mathrm{C}_{6} \mathrm{H}_{5} \mathrm{CH}_{3}$ & $20 / 2$ & - & 78 \\
$\mathrm{PhCH}\left(\mathrm{CH}_{3}\right)$ & $\mathrm{H}$ & $\mathrm{H}$ & $\mathrm{Me}$ & $\mathrm{AlCl}_{3}$ & $\mathrm{C}_{6} \mathrm{H}_{5} \mathrm{CH}_{3}$ & $20 / 4$ & $40: 60$ & 13 \\
$n-\mathrm{Pr}$ & $\mathrm{H}$ & $\mathrm{H}$ & $\mathrm{Me}$ & $\mathrm{BF}_{3} \cdot \mathrm{OEt}_{2}$ & $\mathrm{CH}_{2} \mathrm{Cl}_{2}$ & $20 / 16$ & - & 25 \\
$4-t-\mathrm{Bu}-\left(\mathrm{CH}_{2}\right)_{5}$ & & $\mathrm{H}$ & $\mathrm{Me}$ & $\mathrm{BF}_{3} \cdot \mathrm{OEt}_{2}$ & $\mathrm{CH}_{2} \mathrm{Cl}_{2}$ & $20 / 3$ & - \\
$4-t-\mathrm{Bu}-\left(\mathrm{CH}_{2}\right)_{5}$ & & $\mathrm{H}$ & $\mathrm{Ph}$ & $\mathrm{BF}_{3} \cdot \mathrm{OEt}_{2}$ & $\mathrm{CH}_{2} \mathrm{Cl}_{2}$ & $20 / 3$ & - & 30 \\
\hline
\end{tabular}

Table 10.

\begin{tabular}{|c|c|c|c|c|c|c|}
\hline Acetal & M & L.A. & Conditions & 43-a & 43-b & 43-c \\
\hline $\mathrm{a}$ & $\mathrm{SiMe}_{3}$ & $\mathrm{TiCl}_{4}$ & $\mathrm{CH}_{2} \mathrm{Cl}_{2} /-78^{\circ} \mathrm{C} / 2 \mathrm{~h}$ & 54 & 0 & 36 \\
\hline $\mathrm{a}$ & $\mathrm{SiMe}_{3}$ & $\mathrm{SnCl}_{4}$ & $\mathrm{CH}_{2} \mathrm{Cl}_{2} /-78^{\circ} \mathrm{C} / 2 \mathrm{~h}$ & 55 & 0 & 18 \\
\hline $\mathrm{a}$ & 2 eq. $\mathrm{SiMe}_{3}$ & $\mathrm{BF}_{3} . \mathrm{OEt}_{2}$ & $\mathrm{CH}_{2} \mathrm{Cl}_{2} /-78^{\circ} \mathrm{C} / 2 \mathrm{~h}$ & 40 & 0 & 38 \\
\hline $\mathrm{a}$ & 2 eq. $\mathrm{SiMe}_{3}$ & 2 eq. $\mathrm{BCl}_{3}$ & $\mathrm{CH}_{2} \mathrm{Cl}_{2} /-78^{\circ} \mathrm{C} / 2 \mathrm{~h}$ & 0 & 0 & 20 \\
\hline $\mathrm{a}$ & $\mathrm{SiMe}_{3}$ & $\mathrm{AgClO}_{4}$ & $\mathrm{CH}_{3} \mathrm{NO}_{2} /-40{ }^{\circ} \mathrm{C} / 2 \mathrm{~h}$ & 40 & 0 & 0 \\
\hline $\mathrm{a}$ & $\mathrm{SiMe}_{3}$ & $\mathrm{AgClO}_{4}$ & $\mathrm{CH}_{3} \mathrm{NO}_{2} / 1$ eq. $\mathrm{CaCO}_{3} /-40^{\circ} \mathrm{C} / 2 \mathrm{~h}$ & 62 & 0 & 0 \\
\hline $\mathrm{b}$ & $\mathrm{SiMe}_{3}$ & $\mathrm{TiCl}_{4}$ & $\mathrm{CH}_{2} \mathrm{Cl}_{2} /-78^{\circ} \mathrm{C} / 2 \mathrm{~h}$ & 33 & 0 & 18 \\
\hline $\mathrm{b}$ & $\mathrm{SiMe}_{3}$ & $\mathrm{SnCl}_{4}$ & $\mathrm{CH}_{2} \mathrm{Cl}_{2} /-78^{\circ} \mathrm{C} / 2 \mathrm{~h}$ & 28 & 0 & 20 \\
\hline $\mathrm{c}$ & $\mathrm{SiMe}_{3}$ & $\mathrm{TiCl}_{4}$ & $\mathrm{CH}_{2} \mathrm{Cl}_{2} /-78^{\circ} \mathrm{C} / 2 \mathrm{~h}$ & 20 & 23 & 22 \\
\hline c & $\mathrm{SiMe}_{3}$ & $\mathrm{SnCl}_{4}$ & $\mathrm{CH}_{2} \mathrm{Cl}_{2} /-78^{\circ} \mathrm{C} / 2 \mathrm{~h}$ & 40 & 0 & 35 \\
\hline c & $\mathrm{SiMe}_{3}$ & $\mathrm{AgClO}_{4}$ & $\mathrm{CH}_{3} \mathrm{NO}_{2} / 1$ eq. $\mathrm{CaCO}_{3} /-40^{\circ} \mathrm{C} / 2 \mathrm{~h}$ & 42 & 0 & 0 \\
\hline a & $\mathrm{SnBu}_{3}$ & $\mathrm{TiCl}_{4}$ & $\mathrm{CH}_{2} \mathrm{Cl}_{2} /-78^{\circ} \mathrm{C} / 2 \mathrm{~h}$ & 6 & 0 & 42 \\
\hline a & $\mathrm{SnBu}_{3}$ & $\mathrm{SnCl}_{4}$ & $\mathrm{CH}_{2} \mathrm{Cl}_{2} /-78^{\circ} \mathrm{C} / 2 \mathrm{~h}$ & 20 & 0 & 7 \\
\hline c & $\mathrm{SnBu}_{3}$ & $\mathrm{TiCl}_{4}$ & $\mathrm{CH}_{2} \mathrm{Cl}_{2} /-78^{\circ} \mathrm{C} / 2 \mathrm{~h}$ & 20 & 10 & 30 \\
\hline $\mathrm{c}$ & $\mathrm{SnBu}_{3}$ & $\mathrm{SnCl}_{4}$ & $\mathrm{CH}_{2} \mathrm{Cl}_{2} /-78^{\circ} \mathrm{C} / 2 \mathrm{~h}$ & 36 & 0 & 30 \\
\hline
\end{tabular}

relies on the much stronger $\mathrm{C}-\mathrm{O}$ bond as compared to the $\mathrm{C}-\mathrm{Se}$ bond, giving rise to homoallyl ethers as main products $^{21}$.
Recently we have described the reaction of allylsilanes with tris-(phenylchalcogeno)-methane (S,Se), mediated by tin tetrachloride in the case of selenium derivatives and zinc 
Table 11.

\begin{tabular}{|c|c|c|c|c|c|c|}
\hline Allylsilane & Product & $\mathrm{t}(\mathrm{h})$ & Yield (\%) & Product $^{\mathrm{b}}$ & $\mathrm{t}(\mathrm{h})$ & Yield $^{\mathrm{b}}(\%)$ \\
\hline${\widetilde{\mathrm{SiMe}_{3}}}_{44-\mathrm{a}}$ & 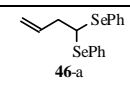 & 1 & $72^{\mathrm{a}}$ & $\overbrace{\substack{\mathrm{SPh} \\
47-\mathrm{a}}}^{\mathrm{SPh}}$ & 24 & 55 \\
\hline$\prod_{44-b} \mathrm{SiMe}_{3}$ & & 1 & $58^{\mathrm{a}}(73)^{\mathrm{b}}$ & & 4.5 & $73^{\mathrm{c}}$ \\
\hline$\overbrace{3} \sim^{\mathrm{SiMe}_{3}}$ & & 1 & $65^{\mathrm{a}}(75)^{\mathrm{b}}$ & & 20 & 59 \\
\hline$\overbrace{44 \mathrm{fiMe}}^{\overbrace{\mathrm{SiMe}_{3}}^{+}}$ & $\begin{array}{l}\text { SePh } \\
46-\mathrm{e}\end{array}$ & 1 & $54^{\mathrm{a}}(69)^{\mathrm{b}}$ & $\underbrace{+}_{47-f}{ }_{S P h}^{\text {SPh }}$ & 24 & 35 \\
\hline
\end{tabular}

a) 2.5 eq of allylsilane;

b) 4 eq of allylsilane;

c) $10 \%$ isomerized product;

d) 1:1 mixture of allylsilanes.

dibromide on sulphur derivatives, Fig. 17. The reaction was studied in detail with several different allylsilanes, as described on the Table $11^{22}$.

All reactions of allylsilanes and tris-(phenylseleno)methane were observed to be completed in one hour or less, while the phenylthio derivative $\mathbf{4 5}$ reacts slower (4.5 h to $24 \mathrm{~h}$ ) than the corresponding phenylseleno derivative as indicated in Table 11. In all cases studied on the reaction of allylsilanes with tris-(phenylseleno)-methane, $\mathrm{SnCl}_{4}$ was the most effective catalyst and $\mathrm{CH}_{2} \mathrm{Cl}_{2}$ was used as solvent. On the other hand, for the sulfur analogue 45, $\mathrm{ZnBr}_{2}$ was the best catalyst and the use of nitromethane as a co-solvent was more effective.

Along with homoallylselenoacetals, small amounts of the corresponding allylmonoselenides were formed, which were easily separated by column chromatography. The formation of these compounds occurs probably by reaction of the allylsilane with a phenylselanyl species formed in the reaction media. This is in accordance with previous ${ }^{23}$ reports that allylsilanes react with $\mathrm{C}_{6} \mathrm{H}_{5} \mathrm{SeCl}$ to give allylselenides. In reactions of $\mathbf{4 4 a - f}$ with $\mathbf{4 5}$ the formation of allylsulfides was not observed.

Homoallylselenides have been prepared by the reaction of selenosulphones with allyltrimethylsilane mediated by a Lewis acid ${ }^{24}$. The best results were obtained with $\mathrm{EtAlCl}_{2}$, as can be seen on the Fig. 18. Similar results were also described for the thio analogs.

\section{Reaction with alkenes}

Recently was described the reaction of mixed Se,O-heteroacetals with alkenes in a intramolecular pathway to produce cyclohexane derivatives, promoted by $\mathrm{TiCl}_{4}$ at low

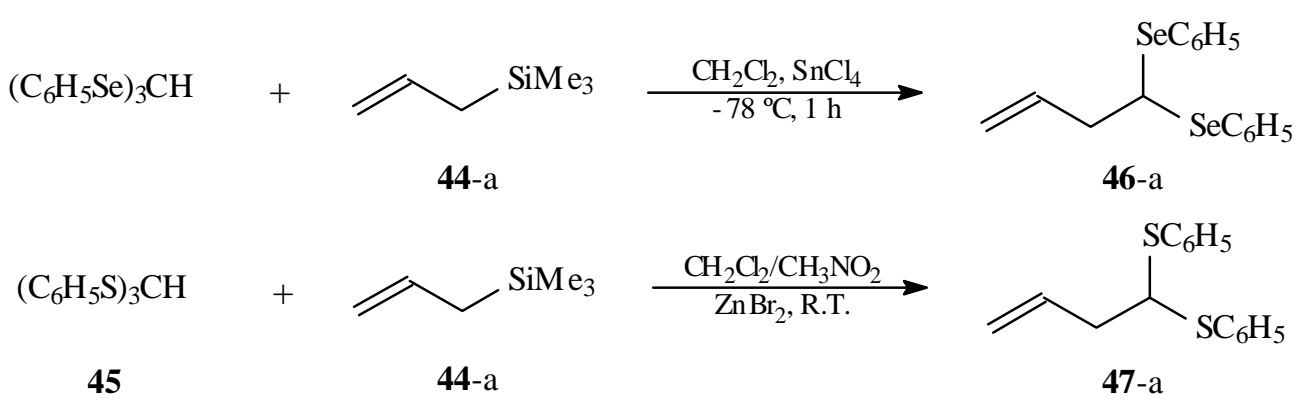

Figure 17.

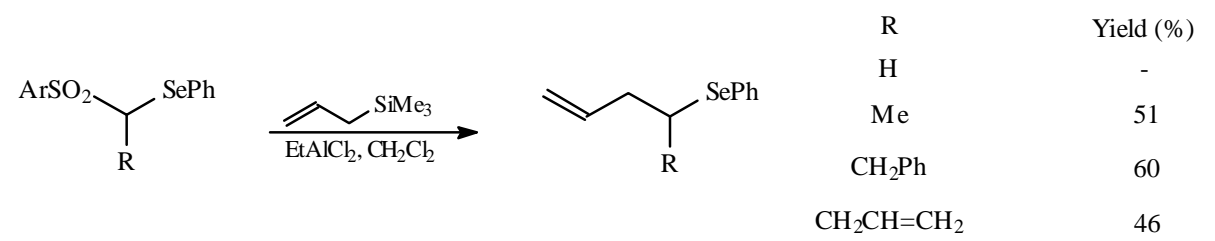

Figure 18. 


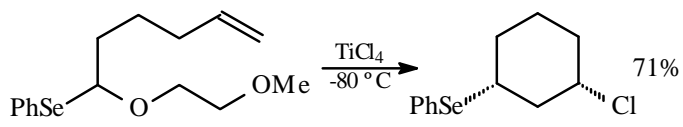<smiles>C/C=C\CCCC(Cc1ccccc1)OCC[C@H]1CCCC(Cl)[C@@H]1C</smiles>

Figure 19.

temperature $^{25}$. In Fig. 19 are presented the results of this study.

A slightly different type of olefin and acetylenic Se,Oheteroacetals gives the corresponding Se-heteroacetals in good yields, as described on Fig. $20^{26}$.

Intramolecular version have been developed emploing cationic cyclizations in the 6-endo fashion, by way of selenonium ion generated from selenoacetals ${ }^{27}$.

Representativelly, in Fig. 21 are described the conditions and yields for the related reactions:

E olefin 50 afforded (1R*, 2S*, 3S*)-1-bromo-2methyl-3-phenylselenocyclohexane $\mathbf{5 1}$ and $Z$ isomer 52 yielded $\left(1 \mathrm{~S}^{*}, 2 \mathrm{~S}^{*}, 3 \mathrm{~S}^{*}\right)$-1-bromo-2-methyl-3-phenylselenocyclohexane 53. These findings indicate that the selenonium ions cause stereospecific cyclization. Reactions of phenylselenoacetals were rather slow, since its Se-C bond are more difficult to be cleaved by Lewis acids than that of methylseleno moiety.

Also, heterocycles containing selenium have been synthesized by an $\left[4^{+}+2\right]$ cationic polar cycloadition. Phenyl $\alpha$-chlorophenacyl selenide 57 reacts in the former route with trans-stilbene in presence of stannic chloride, to form

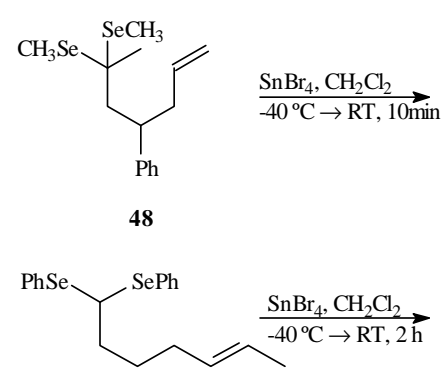

50

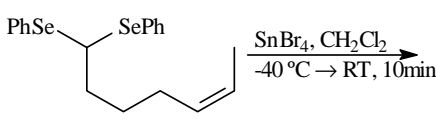

52
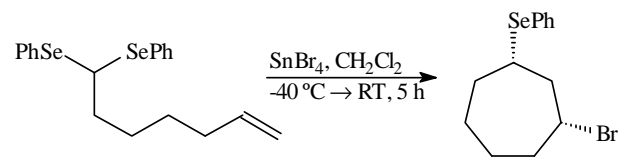

54

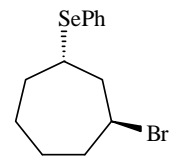<smiles>CC1(C)C[C@@H](Br)C[C@H](Br)C1</smiles>

49<smiles>C[C@H]1[C@H]([18OH])CCC[C@H]1Br</smiles>

51

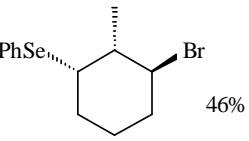

53

$56 \quad 8 \%$

Figure 21.

a trisubstituted selenochroman 58. The reaction probably takes place trought the following mechanism, illustred in Fig. $22^{28}$ :

Besides these results, we have reported recently our results on the reaction of ethyl $\alpha$-chloro- $\alpha$-phenylselenoacetate with alkenes mediated by titanium tetrachloride as Lewis catalyst ${ }^{29}$.

We began our study by reacting 33a with 1 -alkenes in an attempt to prepare $\alpha$-phenylseleno- $\gamma, \delta$-unsaturated esters 60 in an "ene type" reaction: ethyl $\alpha$-chloro- $\alpha$-phenyl-

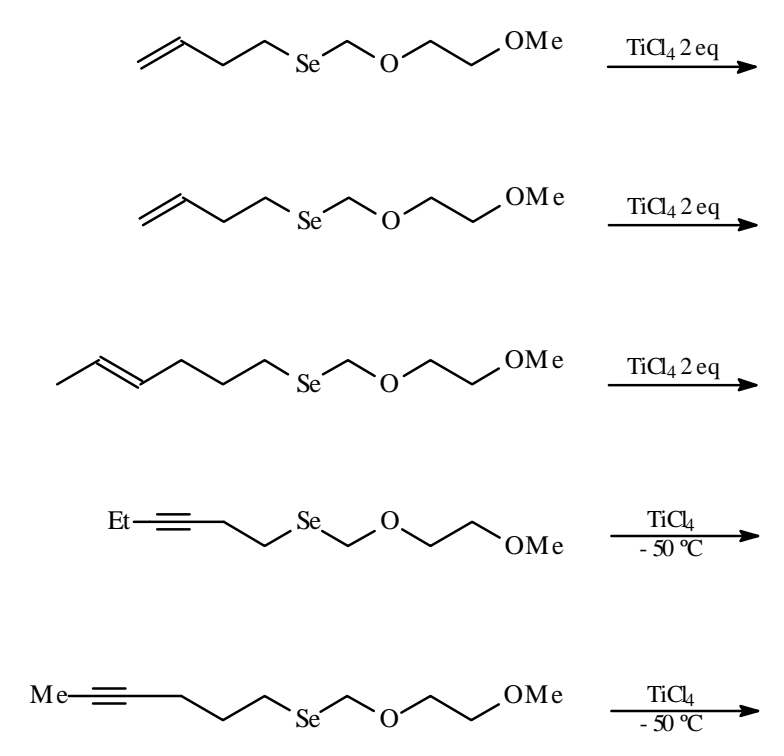

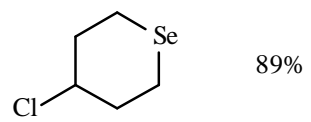
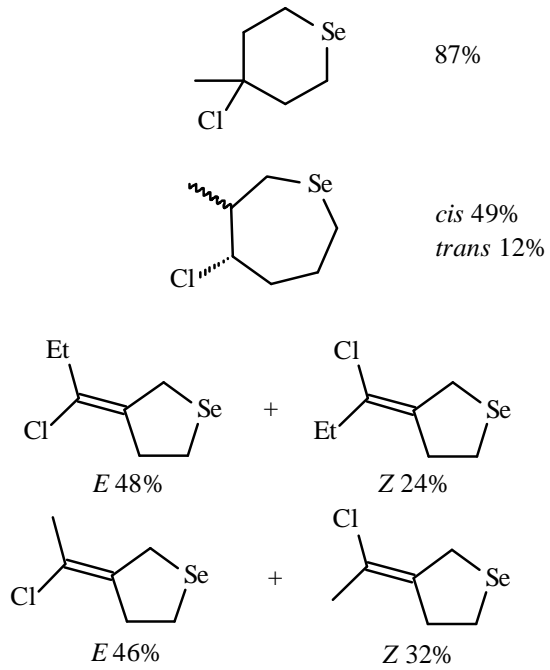

Figure 20. 


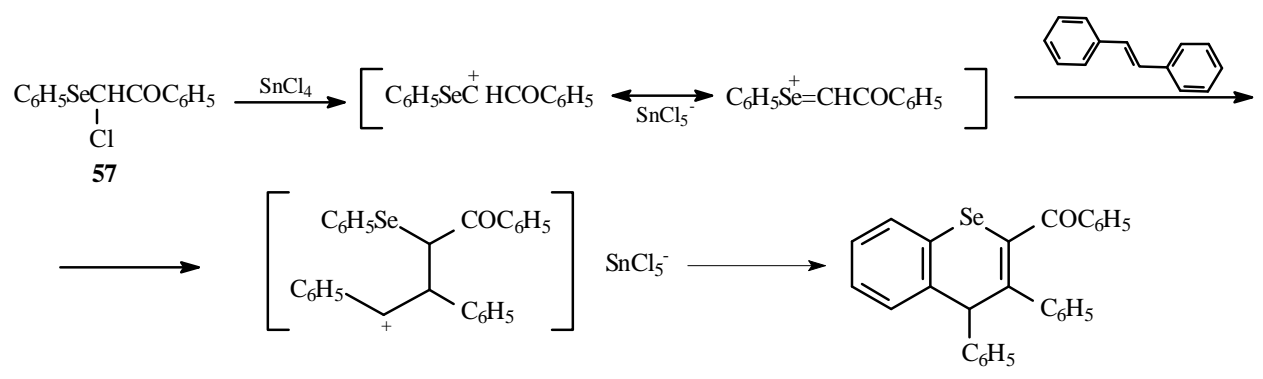

58

Figure 22.

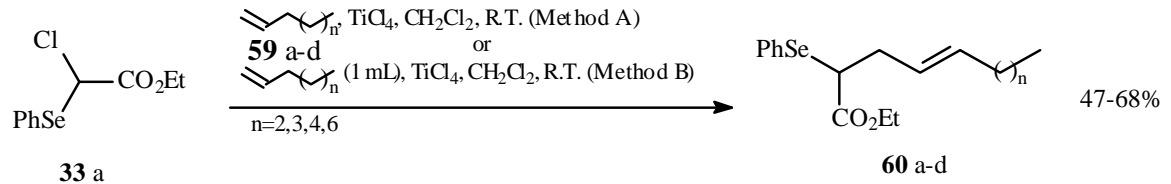

Figure 23.

seleno acetate 33a was treated with 4 different alkenes 59a-d, in a reaction mediated by a Lewis acid, producing $\gamma, \delta$-unsaturated esters 60a-d in good yields (Fig. 23). The $\alpha$-phenylseleno- $\gamma, \delta$-unsaturated esters prepared provide a new convenient way to 2,4-alkanedienoic esters via oxidative deselenation of the adduct $\mathbf{6 0}$.

The reaction of 33a with alkenes 60a-d was promoted by several Lewis acids like $\mathrm{TiCl}_{4}, \mathrm{SnCl}_{4}, \mathrm{ZnCl}_{2}, \mathrm{ZnBr}_{2}$ and $\mathrm{AlCl}_{3}$. Among these Lewis acids $\mathrm{TiCl}_{4}$ was found to give the best yields. Dichloromethane was found to be the best solvent (Method A). The use of the 1-alkene as solvent did not improve yields significantly, but reaction times are reduced (Method B; Table 12).
Since the reaction of 33a with 1-alkenes furnished $\alpha$-phenyl seleno- $\gamma, \delta$-unsaturated esters, we continued our studies to the conversion of these species to $\alpha$-phenylseleno- $\gamma$-butyrolactones. The $\gamma, \delta$ unsaturated $\alpha$-phenylseleno substituted ester $\mathbf{6 0 a}$ derived from the reaction with 1hexene were subjected to hydrolysis with an aqueous $\mathrm{KOH}$ solution and afforded the corresponding carboxylic acid 61a in nearly quantitative yield. The acid was submitted to lactonization with some of the more commom electrophiles $^{29}$ such as iodine, phenylselenenyl chloride, or phenylsulfenyl chloride, to give the highly functionalized lactones of type 62 (Fig. 24). During the seleno and sulfurlactonizations reactions, we observed that the use of tributylamine gives a better yield than triethylamine.

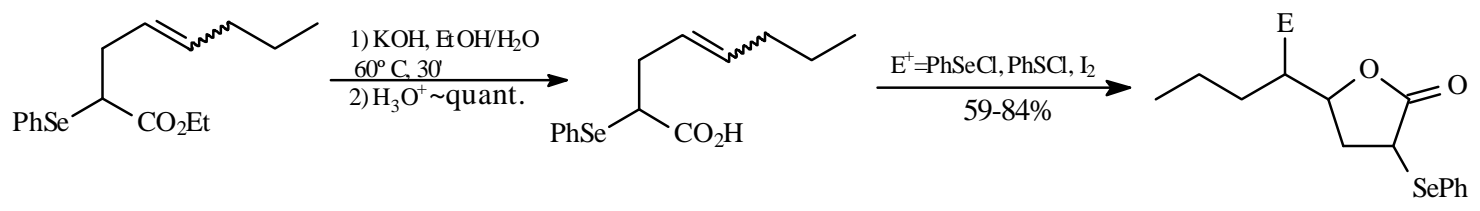

60

61

62

Figure 24.

Table 12.

\begin{tabular}{lccccc}
\hline $\mathbf{6 3}$ & $\mathrm{R}$ & $\mathrm{R}_{1}$ & $\mathrm{R}_{2}$ & $\mathbf{6 4}(\%)$ & $\mathbf{6 5}(\%)$ \\
\hline $\mathrm{a}$ & $\mathrm{CH}_{3}$ & $\mathrm{CH}_{3}$ & $\mathrm{H}$ & 56 & 34 \\
$\mathrm{~b}$ & $\mathrm{CH}_{3}$ & $\mathrm{CH}_{3}$ & $\mathrm{CH}_{3}$ & 64 & 23 \\
$\mathrm{c}$ & $n-\mathrm{C}_{4} \mathrm{H}_{9}$ & $\mathrm{CH}_{3} \mathrm{CH}_{2}$ & $\mathrm{H}$ & 52 & 17 \\
$\mathrm{~d}$ & $\mathrm{CH}_{3}$ & $-\mathrm{CH}_{2} \mathrm{CH}_{2-}$ & 31 & 31 \\
$\mathrm{e}$ & $\mathrm{H}$ & $-\mathrm{CH}_{2} \mathrm{CH}_{2} \mathrm{CH}_{2-}$ & 44 & 43 \\
$\mathrm{f}$ & $\mathrm{CH}_{3}$ & $-\mathrm{CH}_{2} \mathrm{CH}_{2} \mathrm{CH}_{2-}$ & 52 & 32 \\
$\mathrm{~g}$ & $\mathrm{CH}_{3}$ & $-\mathrm{CH}_{2} \mathrm{CH}_{2} \mathrm{CH}(t-\mathrm{Bu}) \mathrm{CH}_{2-}$ & & 48 \\
\hline
\end{tabular}




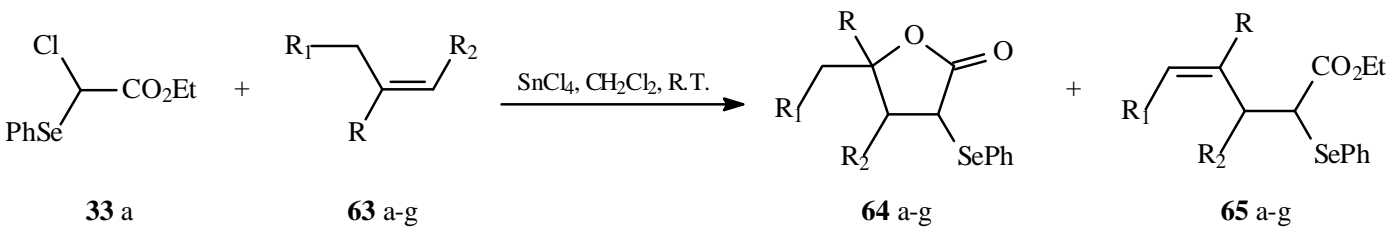

Figure 25.

In view of the formation of $\alpha$-phenylseleno $\gamma, \delta$-unsaturated esters when 1-alkenes were employed which need further transformations to give rise to $\gamma$-butyrolactones, we decided to explore the use of more substituted alkenes, which would produce $\gamma$-butyrolactones directly (Fig. 25, Table 12).

The treatment of a dichloromethane solution of di and tri-substituted alkenes 63a-g with 33a in the presence of $\mathrm{SnCl}_{4}$ yields $\alpha$-phenylseleno- $\gamma$-butyrolactones in variable yields, with the corresponding $\gamma, \delta$-unsaturated ester $\mathbf{6 5}$ being formed as by-product. The ratio between lactone and ester was observed to be dependent of the substitution pattern of the alkene. For example, the reaction of 33a with 1-methyl-cyclohexene gives the corresponding lactone $\mathbf{6 4 f}$ in $52 \%$ yield and the $\gamma, \delta$-unsatured ester $\mathbf{6 5 f}$ in $32 \%$ yield; in the same way, 2-methyl-2-butene gives the lactone in $64 \%$ yield and a $23 \%$ yield of the ester. With less substituted alkenes, like cyclohexene, the corresponding lactone 64e is formed in $44 \%$ yield plus a $43 \%$ yield of $\gamma, \delta$-unsaturated ester 65e (Fig. 26).

For these lactonizations several Lewis acids were tested $\left(\mathrm{SnCl}_{4}, \mathrm{TiCl}_{4}, \mathrm{ZnCl}_{2}, \mathrm{ZnBr}_{2}, \mathrm{AlCl}_{3}\right)$ the best yields being obtained with $\mathrm{SnCl}_{4}$.

\section{Miscellaneous}

Kataoka and co-workers ${ }^{30}$ described recently the reaction of $\gamma$-chalcogen substituted prop-2-ynyl cations, generated from $\gamma$-chalcogen-substituted propynal diethylacetals with several nucleophiles. The starting material $\mathbf{6 8}$ were prepared by reaction of propynal diethyl acetal with ethylmagnesium bromide followed by treatment with ben- zenesulfenyl or benzeneselenenyl chloride (Fig. 27). The reaction of these reagents with nucleophiles are shown in Table 13.

Table 13.

Acetal Sicleophile (\%)<smiles>CCOC(=O)C(Cl)C(=O)OCCCCCCCCCC(C(=O)OCC)C1C=CCCC1</smiles>

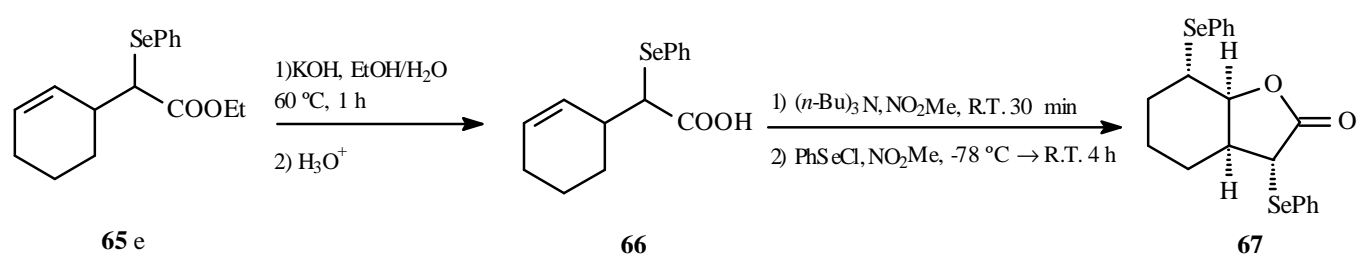

Figure 26. 


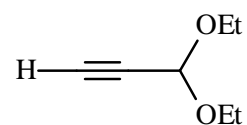

68

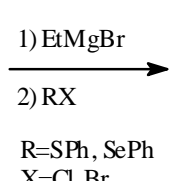

$\mathrm{X}=\mathrm{Cl}, \mathrm{Br}$

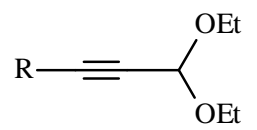

69
Figure 27.

\section{Acknowledgments}

The autor is deeply indebted to the graduate and undergraduate co-workers mentioned in this article. We gratefully acknowledge CAPES, CNPq, PADCT, GTZ and FAPERGS for financial support.

\section{References}

1. Paulmier, C. In The Selenium Reagents and Intermediates in Organic Synthesis; Baldwin, J. E., Ed.; Pergamon Books Ltd.: New York, 1986.

2. Hevesi, L. Phosphorus and Sulfur 1988, 38, 191. Hevesi, L. Bull. Soc. Chim. Fr. 1990, 127, 697.

3. Renard, M.; Hevesi, L. Tetrahedron Lett. 1983, 24, 3911.

4. Halazy, S.; Hevesi, L. J. Org. Chem. 1983, 48, 5242.

5. Renard, M.; Hevesi, L. J. Chem. Soc., Chem. Commun. 1986, 688.

6. Hevesi, L.; Renard, M.; Proess, G. J. Chem. Soc., Chem. Commun. 1986, 1725.

7. Proess, G.; Pankert, D.; Hevesi, L. Tetrahedron Lett. 1992, 33, 269.

8. Silveira, C.C.; Lenardão, E.J.; Comasseto, J.V.; Dabdoub, M.J. Tetrahedron Lett. 1991, 32, 5741.

9. Dabdoub, M.J.; Guerrero Jr., P.G.; Silveira, C.C. J. Organometal. Chem. 1993, 460, 31.

10. Silveira, C.C.; Lenardão, E.J.; Comasseto, J.V. Synthetic Commun. 1994, 24, 575.

11. Nsunda, K.M.; Hevesi, L. Tetrahedron Lett. 1984, 4441.

12. Silveira, C.C.; Comasseto, J.V.; Catani, V. Synthetic Commun. 1985, 15, 931; Silveira, C.C.; Comasseto, J.V. An. Acad. bras. Ci. 1988, 60, 173.

13. Petragnani, N.; Rodrigues, R.; Comasseto, J.V. J. Organomet. Chem. 1976, 114, 281.
14. Dumont, W.; Sevrin, M.; Krief, A. Angew. Chem., Int. Ed. Engl. 1977, 16, 541.

15. Comasseto, J.V.; Silveira, C.C. Synthetic Commun. 1986, 16, 1167.

16. Hevesi, L.; Nsunda, K.M. Tetrahedron Lett. 1985, 26, 6513.

17. Hevesi, L.; Lavoix, A. Tetrahedron Lett. 1989, 30, 4433.

18. Silveira, C.C.; Braga, A.L.; Machado, A.; Fiorin. G.L.; Dabdoub. M.J. Tetrahedron Lett. 1996, 37, 9173.

19. Yoshimatsu, M.; Machida, K.; Seseya, T.; Shimizu, H.; Kataoka, T. J. Chem. Soc., Perkin Trans I 1996, 1839.

20. Hermans, B.; Hevesi, L. Bull. Soc. Chim. Belg. 1994, 103, 257; Hermans, B.; Hevesi, L. Tetrahedron Lett. 1990, 31, 4363. See also Krief, A.; Badaoui, E.; Dumont, W.; Hevesi, L.; Hermans, B.; Dieden, R. Tetrahedron Lett. 1991, 32, 3231.

21. Hermans, B.; Hevesi, L. J. Org. Chem. 1995, 60, 6141.

22. Silveira, C.C.; Fiorin, G.L.; Braga, A.L. Tetrahedron Lett. 1996, 37, 6085.

23. Nishiyama, H.; Itagaki, K.; Sakuta, K.; Itoh, K. Tetrahedron Lett. 1981, 22, 5285; Nishiyama, H.; Itoh, K. Tetrahedron Lett. 1981, 22, 5289.

24. Simpkins, N. Tetrahedron 1991, 47, 323.

25. Yoshimatsu, M.; Fujimoto, M.; Shimizu, H.; Hori, M.; Kataoka, T. Chem. Pharm. Bull. 1993, 41, 1160.

26. Yoshimatsu, M.; Sato, T.; Shimizu, H.; Hori, M.; Kataoka, T. J. Org. Chem. 1994, 59, 1011.

27. Kataoka, T.; Yoshimatsu, M.; Shimizu, H.; Hori, M. Tetrahedron Lett. 1991, 32, 105.

28. Magdesieva, N.N.; Krylov, A.N.; Magdesieva, T.V. Zh. Org. Khim. 1991, 27, 1701.

29. Silveira, C.C.; Lenardão, E.J.; Araujo, M.A.; Braga, A.L.; Dabdoub, M. J. Synthesis 1995, 1305 and references therein.

30. Yoshimatsu, M.; Shimizu, H.; Kataoka, T. J. Chem. Soc., Chem. Commun. 1995, 149. 